\title{
Re-globalisation and Supply Chain Reshoring: Motivation and Performance of Global Companies in Korea
}

\author{
Eon-Seong Lee ${ }^{1}$ \\ ${ }^{1}$ Professor, School of Business, Pusan National University, Korea, eslee@ pusan.ac.kr
}

\begin{abstract}
This study examines how reshoring-related motivations and performances, in response to reglobalisation, of global firms operating in Korea are different by country and industry. It develops six reshoring motivational factors with twenty-six items and three performance indicators with seven items, and analyses differences by countries (i.e., US, Japan and Korea) and by industries (i.e., traditional manufacturing, and technology and knowledge-based industries) for each item. Four hypotheses projecting the differences of reshoring motivations and performances are established from literature. Survey data are collected from global companies currently operating in Korea that have had reshoring experiences. A total of fifty-three (53) companies responded to the survey. This paper analysed differences in reshoring motivation and performance in the three countries by conducting a one-way analysis of variance to test the hypotheses. The results show statistically significant differences in terms of reshoring motivations and performances by countries, and noticeable differences by industries. American and Japanese firms are siliar in respect of reshoring motivation and performance, while Korean counterparts are different with regard to customer service, labour and country factors from the reshoring motivation, and the cost and organizational innovation elements from the reshoring performance. The research findings are an interesting addition to the literature given that existing differences for reshoring motivation and performance by country and industry were empirically examined in a local context. The results presented by the study is intended to provide strategic insights into the logistics and operational decisions to be considered when making reshoring-related decisions, as well as how to effectively manage dispersed global supply chains in an era of re-globalisation.
\end{abstract}

Keywords: Reshoring Motivation and Performance, Global Supply Chains and Operations, Global Firms, Local Context, Differences by Country and Industry

\section{Introduction}

In past decades, with the rapid globalization of markets and production factors, international companies relocated their overseas production bases to countries with low production costs. Increasing foreign direct investment also facilitated these offshoring movements, which tended to have various strategic motives. As a result, the global supply chains of international companies widened geographically and became increasingly complex. However, in recent years, there have been many changes in foreign investment patterns, such as the restructuring of the global supply chain. In contrast to the previous trend of expanding overseas production, many companies (e.g. in advanced countries such as the US, Japan and European countries) have moved their overseas production bases back to their home countries. The business decision to revise an existing offshore strategy and relocate a foreign production base back in the home country is termed 'reshoring'. Governments of home countries tend to expect considerable benefits from reshoring growth, including the creation of new jobs and the

Received: September 6, 2021; $1^{\text {st }}$ Review Result: October 21, 2021; $2^{\text {nd }}$ Review Result: December 10, 2021 Accepted: January 29, 2022 
stimulation of economic recovery[1][2].

In accordance with this shift in global supply chain management, many studies have examined the phenomenon of global firm reshoring and its various effects. For example, existing studies have examined the following: the factors that promote and interfere with reshoring[3]; the determinants of reshoring[2]; reshoring processes[1]; and the characteristics and status of reshoring[4]. Other studies have investigated the job creation effect of reshoring and the economic impact of reshoring on the home country[5]. However, despite reshoring's significance, prior studies have not systematically analysed companies' reshoring motivations or the impact of reshoring on firm performance. Moreover, existing studies have mainly addressed reshoring in advanced countries such as the US, Japan, and Europe rather than in less advanced countries such as Korea. In addition, the analyses' results regarding the determinants and effectiveness of reshoring have varied with the industries studied. These variations suggest that reshoring motivation and performance might be subject to such variables as industry type and a country's economic level.

In light of the above contention, the following questions arise: what precisely are global companies' motivations for reshoring and do reshoring strategies truly help companies improve their performance? Do international companies that are actively reshoring in less advanced countries have the same motivations as those in developed countries, and is their performance similarly improved? Do the expected effects of reshoring apply equally to all industries, or are greater effects expected in a particular industry, such as traditional manufacturing or the advanced technology industry? The purpose of this study is to systematically examine companies' reshoring motivations and organizational performance. The study also empirically investigates whether home countries and the industrial types of reshoring companies can control reshoring motivations and performance. The results of this study may have strategic implications for companies planning to reshore in the future, from the perspective of global supply chain management.

This paper consists of the following sections. First, a literature review introduces the concept of reshoring and its strategic significance in modern global supply chain management. The literature review establishes the theoretical basis for identifying an international firm's reshoring status and its impact on organizational performance. The relevant hypotheses are then developed. Finally, the last section presents the empirical analysis and the discussion.

\section{Literature Review}

Many studies have explored the reshoring motivations of global firms, and one of the most important motives identified has been the cost factor. In general, foreign investment decisions of companies have been based on the lower costs and wages that can often be found abroad. Recently, however, these costreduction benefits have been waning. Labour wages in local countries have begun to rise, while productivity has not been as high as expected. In addition, as offshoring has proliferated across the globe, supply chains have become more complex, increasing the cost of global logistics. Reshoring decisions cannot be explained on the basis of cost alone, pointing out that small- and medium-sized enterprises have recently been transferring their manufacturing processes from low-cost countries to high-cost home countries[1]. This may be due to a lack of skilled workers in the host country, and a resulting loss in innovation potential. This may lead to a poor quality of offshore production. Furthermore, as the complexity of global supply chains has increased with an increasing number of host countries, companies faced reduced operational flexibility and, at the same time, increased global logistics and supply chain coordination costs. Therefore, companies may return production to their home countries to lower these costs. In addition, offshoring presented a risk of losing know-how to local companies. Yet another reason behind the decision to reshore is to reacquire the "made in" effect from producing in 
home countries[6]. Based on the existing literature, this study categorises reshoring drivers into the following seven factors: quality improvement and brand image enhancement agenda; response to changes in country factor costs; reconfiguration and restructured costs; enhanced innovation capability; improved customer responsiveness; risk management and supply dependability; and institutions. This study empirically analyses the reshoring motivations of international firms in terms of these seven factors.

Existing studies on the performance of reshoring companies have focused mainly on the economic effects on the home country. For example, the job creation effect of reshoring is high in Europe[7]. Meanwhile, the economic effects of reshoring are still being actively debated[8]. Although the debate on the actual effects of reshoring continues, many advanced countries (e.g., Germany, France, UK, and US) have adopted policies to support reshoring. Not showing consistent results, the aforementioned findings imply that reshoring can have positive or negative effects on a home country economy. However, most studies have predominantly focused on the economic effects of reshoring in a home country. Few studies have empirically analysed the performance of individual reshoring companies. Therefore, this study will examine whether individual companies' reshoring decisions have a positive effect on their performance.

As discussed earlier, the major determinants of companies' reshoring decisions include country factors, production flexibility, quality improvement, brand image enhancement, risk management, and cost savings in supply chain management. However, the motives of reshoring companies may differ by country or industry. For example, studies on reshoring by American and German businesses show clear differences between the two countries. American businesses consider production cost as a major motivation to reshore, while German businesses tend to emphasize qualitative factors, such as supply elasticity or product quality improvement. Meanwhile, Japan has implemented reshoring incentive policies to stimulate local industries and economies. For example, the former Prime Minister Abe designated a total of ten national strategic special zones throughout Japan, advocating for deregulation to foster regional industries so that overseas Japanese companies could return home. As a result, many Japanese companies returned to take advantage of the strong incentives, which also succeeded in attracting more foreign companies to Japan[9]. Compared to companies reshoring in advanced countries, companies reshoring in less developed countries would tend to have different motives. For example, in the case of Korea, wage increases in major investment countries, such as China, were not found to be a significant factor in reshoring decisions. In fact, Korean companies are continuing to increase their foreign investments, as they are facing increasing demand to localize production abroad. For this reason, businesses that have invested abroad are unlikely to reshore in Korea even with the support and encouragement of the Korean government. Rather, it is highly likely that reshoring in Korea could occur in high value-added fields and industries such as $\mathrm{R} \& \mathrm{D}$, design, and technology. Therefore, the Korean government is seeking to develop an institutional incentive system for reshoring to attract high-valueadded industries rather than to simply support reshoring for cost-saving companies[10]. The following hypothesis is accordingly established.

\section{$H_{1}$ : Global companies' motivation for reshoring differs from country to country.}

Alternatively, the motivation for reshoring may depend on the characteristics of an industry. Traditional manufacturing companies such as those in apparel, textile, footwear, automobile, and machinery parts industries that have invested in low-wage countries to exploit low costs of production tend to reshore in home countries due to rising wages in local countries. Meanwhile, advancedtechnology-related manufacturing and its $R \& D$ industry (e.g., information and communication technology, industries related to the Fourth Industrial Revolution that use artificial intelligence, Internet of Things (IoT) and 3D printing technology, and electric and autonomous vehicles) are motivated to 
reshore based on advanced social infrastructure and skilled labour in their home countries. Therefore, this study classifies industries into the following two types: traditional manufacturing; and technology and knowledge-based industries. The study then analyses whether there are differences between these industry types in terms of reshoring motivations. The following hypothesis, based on what has been discussed above, is established. .

\section{$\mathrm{H}_{2}$ : Global companies' motivation for reshoring differs from industry to industry.}

In the short term, companies undergoing reshoring may experience an increase in costs from the relocation. These are the costs of moving their production facilities from overseas areas to home countries, establishing new production facilities in home countries, and relocating employees. Reshoring companies' financial performance may temporarily decline due to these short-term cost increases, but it may improve in the mid- to long- term as the company benefits from home country incentives and productivity improvements. In addition, companies may improve their strategic performance through reshoring. For example, a company's productivity may improve with higher quality employees, and its product quality and brand image could be enhanced. Moreover, transportation and logistics costs may be reduced as a result of supply chain simplification after reshoring. Reshoring seems to be a universal trend around the world, but if we examine it in detail, there may be distinct performance differences across countries or industries. For example, reshoring policies emerged in the US starting in the late 2000s, and they have continued to expand in advanced countries, such as in European countries and Japan[11]. A common characteristic of reshoring performance in developed countries is that the job creation effect from a reshoring decision is quite large[10][11]. In all, reshoring has created 576,000 jobs in the US since 2010, and it has been reported that reshored companies in the US will continue to improve their competitiveness. In fact, from 2010 to 2018, the employment effect from reshoring in the US increased by $2,300 \%$. Although it may have, in part, stemmed from national macroeconomic effects, experts claim that the expansion of corporate reshoring was a major driver of the increase. In addition, the increased employment of international companies in their home countries means that the financial performance of the reshoring companies would also continue[11]. On the other hand, the reshoring performance in less developed countries would be different. In contrast to the above cases, Korea actually has a very low percentage of reshoring companies compared to those offshoring, and the country's trend of domestic companies expanding overseas and offshoring does not appear likely to change anytime soon. In addition, the financial and strategic performance of reshoring in less developed countries is not as clear as that in developed countries. This leads us to the following hypothesis.

\section{$H_{3}$ : Global companies' reshoring performance varies from country to country.}

Reshoring performance may vary by industry. Companies' motives for reshoring also vary by industry, and the expected effects and actual performance may be different. On the one hand, traditional manufacturing firms that have invested in low-wage foreign countries to exploit low costs of production face diminished cost advantages when local wages increase. When the home country government offers cost incentives to attract corporate reshoring, these manufacturing companies may decide to reshore to gain advantages. Thus, traditional manufacturing firms can further increase their cost efficiency and financial performance through reshoring. On the other hand, in the case of advanced technology and knowledge-based manufacturing, if the human resources and infrastructure in the home country's information technology or high-tech fields are very developed, a company will actively reshore even if the operational costs in the home country are high. In addition, advanced-technology-related manufacturing companies can further enhance their international competitiveness in new technology, $\mathrm{R} \& \mathrm{D}$, and organizational innovation through reshoring. Against this backdrop, this study presents the 
following hypothesis.

\section{$H_{4}$ : Global companies' reshoring performance varies from industry to industry.}

\section{Research Methodology}

\subsection{Research Method}

This paper adopts a quantitative research method to statistically test those established hypotheses. A survey method is used to collect the quantitative data. The following sections present the construct operationalization to measure the variables, the sampling strategy, and the data collection methods. The constructs for the hypothesis testing have been operationalized for measurement and are based on comprehensive literature that empirically measured and tested the relevant constructs. All the variables presented in this section were measured on a five-point rating scale, and the questionnaire was developed on the basis of those measurements. This paper empirically analyses the differences between countries in terms of reshoring motivation and performance, using the examples of the US, Japan, and Korea. Data were collected from international companies with subsidiaries in Korea and with headquarters in the US, Japan, and Korea. While the US ranks first based on GDP (gross domestic product; i.e. $\$ 21,433,226$ as of 2020) and Japan ranks 3rd (i.e. $\$ 5,081,770$ as of 2020), Korea ranks 12th (i.e. $\$ 1,646,739$ as of 2020)[12]. This indicates that the level of economic development is very high in the US and Japan, and relatively lower in Korea. Meanwhile, sample firms were identified using Korea Trade-Investment Promotion Agency (KOTRA)'s directory of global firms that had entered Korea. A Korean governmental organization under the Ministry of Trade, Industry and Energy, KOTRA provides publicly credible data on foreign investment and trade to the public regularly[13].

\subsection{Data Collection}

There were a total of two thousand and seventy-eight $(2,078)$ companies, and a survey was conducted among five-hundred (500) randomly selected companies. This study filtered the sample companies by asking whether they had at least one reshoring experience. The survey targets were limited to employees who were at the team-leader level or higher who were familiar with the headquarter's international management strategy. Over a period of 1.5 months in 2020, a total of fifty-three (53) individuals responded to the survey. There were thirty (30) American companies, twelve (12) Japanese companies, and eleven (11) Korean ones.

\section{Data Analysis Results}

[Table 1] shows the descriptive statistics of the variables. To test the Hypothesis 1, we analysed differences in reshoring motivations in the three countries by conducting a one-way analysis of variance using IBM SPSS25 software. This method aimed to detect differences in motivation across countries. The results are presented in [Table 2] to [Table 9]. As shown in the tables, motivational differences by country are found in all items of customer service, 1 item of risk management, 2 items of the labour factor, and 3 items of the country factor. The result shows that while there are no differences the reshoring motivation in terms of the reconfiguration and restricted cost factor, there are statistically significant differences in the customer service factor among the three countries. The post-hoc analysis showed that the US and Japan are categorized in the same group while Korea is different, showing that the means for the US and Japan are higher than those of Korea. This result implies that companies in the US and Japan make reshoring decisions to improve their customer service more than Korean 
companies do. As shown in [Table 4] and [Table 5], while there are no differences in reshoring motivation in terms of supply chain efficiency and the flexibility factor, there are statistically significant differences in the risk management factor among the three countries, partially in the two items, RM2 and RM5. The post-hoc analysis showed that in RM2, the means of the three countries are all different, with Korea having the highest mean, followed by the US and Japan. Also for RM2, the means of the three countries are all different, with the US having the highest mean, followed by Japan and Korea. This implies that in terms of local security, Korea is the most sensitive in making reshoring decisions. When it comes to needing certainty around delivery times, the US appears to have the strongest motive for reshoring.

[Table 1] Descriptive Statistics

\begin{tabular}{|c|c|c|c|c|}
\hline \multicolumn{2}{|l|}{ Variables } & $\mathbf{N}$ & Mean value & Standard deviation \\
\hline \multirow{3}{*}{$\begin{array}{l}\text { Reconfiguration and restricted } \\
\text { cost }\end{array}$} & RR1 & 53 & 3.8868 & .72484 \\
\hline & RR2 & 53 & 3.9057 & .68680 \\
\hline & RR3 & 53 & 4.1509 & .66205 \\
\hline \multirow{5}{*}{ Customer services } & CS1 & 53 & 3.7736 & .69729 \\
\hline & $\mathrm{CS} 2$ & 53 & 3.9245 & .58339 \\
\hline & CS3 & 53 & 4.0000 & .75955 \\
\hline & CS4 & 53 & 3.8868 & .86958 \\
\hline & CS5 & 53 & 3.9811 & .84331 \\
\hline \multirow{3}{*}{$\begin{array}{l}\text { Supply chain efficiency and } \\
\text { flexibility }\end{array}$} & SEF1 & 53 & 3.5283 & .60776 \\
\hline & SEF2 & 53 & 3.6226 & .62716 \\
\hline & SEF3 & 53 & 3.6792 & .72784 \\
\hline \multirow{5}{*}{ Risk management } & RM1 & 53 & 4.1698 & .46969 \\
\hline & RM2 & 53 & 4.1321 & .52027 \\
\hline & RM3 & 53 & 4.3396 & .73231 \\
\hline & RM4 & 53 & 4.2264 & .54213 \\
\hline & RM5 & 53 & 4.1509 & .74411 \\
\hline \multirow{3}{*}{ Labour factors } & LF1 & 53 & 3.8679 & .89952 \\
\hline & LF2 & 53 & 3.8491 & .86372 \\
\hline & LF3 & 53 & 2.6226 & .73971 \\
\hline \multirow{6}{*}{ Country factors } & CF1 & 53 & 3.6415 & .96266 \\
\hline & CF2 & 53 & 4.0755 & .58339 \\
\hline & CF3 & 53 & 4.1698 & .67185 \\
\hline & CF4 & 53 & 3.8679 & .70813 \\
\hline & CF5 & 53 & 3.8491 & .84116 \\
\hline & CF6 & 53 & 3.9623 & .78354 \\
\hline \multirow{2}{*}{ Cost } & Cst1 & 53 & 3.2642 & .73774 \\
\hline & Cst2 & 53 & 3.2830 & .79366 \\
\hline \multirow{3}{*}{ Quality } & Qu1 & 53 & 3.9057 & .56378 \\
\hline & Qu2 & 53 & 4.0566 & .49672 \\
\hline & Qu3 & 53 & 3.8113 & .70864 \\
\hline \multirow{2}{*}{ Organizational Innovation } & OI1 & 53 & 3.9434 & .63291 \\
\hline & OI2 & 53 & 3.9811 & .57145 \\
\hline
\end{tabular}

[Table 2] Differences in Reshoring Motivation by Country: Reconfiguration and Restricted Cost

\begin{tabular}{|c|c|c|c|c|c|c|}
\hline \multicolumn{2}{|c|}{ Source of difference } & Squared sum & $\begin{array}{l}\text { Degree of } \\
\text { freedom }\end{array}$ & $\begin{array}{l}\text { Mean } \\
\text { Square }\end{array}$ & $\mathbf{F}$ & Significance \\
\hline \multirow{3}{*}{ RR1 } & Between groups & .028 & 2 & .014 & .026 & .974 \\
\hline & Within groups & 27.292 & 50 & .546 & & \\
\hline & Total & 27.321 & 52 & & & \\
\hline \multirow{3}{*}{ RR2 } & Between groups & .819 & 2 & .410 & .864 & .428 \\
\hline & Within groups & 23.709 & 50 & .474 & & \\
\hline & Total & 24.528 & 52 & & & \\
\hline \multirow{3}{*}{ RR3 } & Between groups & .167 & 2 & .083 & .184 & .832 \\
\hline & Within groups & 22.626 & 50 & .453 & & \\
\hline & Total & 22.792 & 52 & & & \\
\hline
\end{tabular}


[Table 3] Differences in Reshoring Motivation by Country - Customer Service

\begin{tabular}{|c|c|c|c|c|c|c|}
\hline \multicolumn{2}{|c|}{ Source of difference } & Squared sum & $\begin{array}{c}\text { Degree of } \\
\text { freedom }\end{array}$ & $\begin{array}{c}\text { Mean } \\
\text { Square }\end{array}$ & F & Significance \\
\hline \multirow{4}{*}{ CS1 } & Between groups & 8.500 & 2 & 4.250 & 12.661 & .000 \\
\cline { 2 - 7 } & Within groups & 16.783 & 50 & .336 & & \\
\cline { 2 - 7 } & Total & 25.283 & 52 & & & .000 \\
\hline \multirow{4}{*}{ CS2 } & Between groups & 7.945 & 2 & 3.973 & 20.366 & \\
\cline { 2 - 7 } & Within groups & 9.753 & 50 & .195 & & .000 \\
\cline { 2 - 7 } CS3 & Total & 17.698 & 52 & & & \\
\hline & Between groups & 14.283 & 2 & 7.142 & 22.720 & .000 \\
\cline { 2 - 7 } & Within groups & 15.717 & 50 & .314 & & \\
\hline \multirow{3}{*}{ CS4 } & Total & 30.000 & 52 & & & .000 \\
\cline { 2 - 7 } & Between groups & 22.392 & 2 & 11.196 & 33.068 & \\
\cline { 2 - 7 } & Within groups & 16.929 & 50 & .339 & & \\
\hline \multirow{3}{*}{ CS5 } & Total & 39.321 & 52 & & & \\
\cline { 2 - 7 } & Between groups & 22.016 & 2 & 11.008 & 36.779 & \\
\cline { 2 - 7 } & Within groups & 14.965 & 50 & .299 & & \\
\hline
\end{tabular}

[Table 4] Differences in Reshoring Motivation by Country: Supply Chain Efficiency and Flexibility

\begin{tabular}{|c|c|c|c|c|c|c|}
\hline \multicolumn{2}{|c|}{ Source of difference } & Squared sum & $\begin{array}{l}\text { Degree of } \\
\text { freedom }\end{array}$ & Mean Square & $\mathbf{F}$ & Significance \\
\hline \multirow{3}{*}{ SEF1 } & Between groups & 1.455 & 2 & .727 & 2.048 & .140 \\
\hline & Within groups & 17.753 & 50 & .355 & & \\
\hline & Total & 19.208 & 52 & & & \\
\hline \multirow{3}{*}{ SEF2 } & Between groups & 1.124 & 2 & .562 & 1.454 & .243 \\
\hline & Within groups & 19.329 & 50 & .387 & & \\
\hline & Total & 20.453 & 52 & & & \\
\hline \multirow{3}{*}{ SEF3 } & Between groups & 1.527 & 2 & .764 & 1.468 & .240 \\
\hline & Within groups & 26.020 & 50 & .520 & & \\
\hline & Total & 27.547 & 52 & & & \\
\hline
\end{tabular}

As shown in [Table 6] and [Table 7], the three countries differ in terms of reshoring motivation in several labour and country factors. Firstly, in LF1 and LF2, the US and Japan are in the same group, with higher mean values than those of Korea. This implies that the US and Japan are more motivated by the skilled workforce availability and labour productivity in their home countries than is Korea. Regarding CF1 and CF4, the US and Japan are in the same group, with higher means than that of Korea. This suggests that companies in the US and Japan are more motivated to utilize local resources compared to Korean companies. In CF4, the three countries differ from each other, with Japan having the highest mean and the US and Korea following. [Table 8] shows differences in reshoring performance by country. The reshoring performance of the countries are different in terms of cost-saving factors. While the US and Japan are in the same group, both with mean values above 3.0, Korea had a mean value of 2.6. Although for the two cost factors, the mean values of the US and Japan are slightly higher that of Korea, a mean value of mid-3 points means that the cost saving performance would not be substantial. Meanwhile, the Korean companies' mean value of mid-2 points ensures that these companies' reshoring performance would be very low in terms of cost savings. Regarding the organizational performance factor (OI2), the US and Japan have higher mean values than that of Korea, and this difference is statistically significant. To test the Hypothesis 3 , this paper classified the responding companies into the following two industry types: the traditional manufacturing industry (i.e., companies that product textiles, machinery and auto parts) and the advanced technology industry (i.e., the knowledge and technology-based industry: there are thirty-five (35) companies in the traditional manufacturing category and eighteen (18) in the advanced technology industry. First, the traditional manufacturing companies focuses on achieving economies of scale using existing manufacturing techniques. In this industry, labour productivity and cost and resource efficiency are expected to more strongly impact 
offshoring motivation. The second type of industry requires the development of new, innovative technologies and has been profoundly affected by the Fourth Industrial Revolution. Semiconductors, solar power generation, technology test and inspection services, OLED fine chemical materials, solar cell development, and information and communication services are examples of this type of industry. This type requires more highly skilled manpower for research and production rather than simply requiring an inexpensive workforce. Therefore, more advanced infrastructure in $R \& D$ and production areas can be a determining factor in reshoring.

[Table 5] Differences in Reshoring Motivation by Country: Risk Management

\begin{tabular}{|c|c|c|c|c|c|c|}
\hline \multicolumn{2}{|c|}{ Source of difference } & Squared sum & $\begin{array}{l}\text { Degree of } \\
\text { freedom }\end{array}$ & $\begin{array}{l}\text { Mean } \\
\text { Square }\end{array}$ & $\mathbf{F}$ & Significance \\
\hline \multirow{3}{*}{ RM1 } & Between groups & .119 & 2 & .059 & .261 & .771 \\
\hline & Within groups & 11.353 & 50 & .227 & & \\
\hline & Total & 11.472 & 52 & & & \\
\hline \multirow{3}{*}{ RM2 } & Between groups & 2.215 & 2 & 1.107 & 4.669 & .014 \\
\hline & Within groups & 11.861 & 50 & .237 & & \\
\hline & Total & 14.075 & 52 & & & \\
\hline \multirow{3}{*}{ RM3 } & Between groups & 1.043 & 2 & .521 & .971 & .386 \\
\hline & Within groups & 26.844 & 50 & .537 & & \\
\hline & Total & 27.887 & 52 & & & \\
\hline \multirow{3}{*}{ RM4 } & Between groups & .950 & 2 & .475 & 1.656 & .201 \\
\hline & Within groups & 14.333 & 50 & .287 & & \\
\hline & Total & 15.283 & 52 & & & \\
\hline \multirow{3}{*}{ RM5 } & Between groups & 8.599 & 2 & 4.299 & 10.645 & .000 \\
\hline & Within groups & 20.194 & 50 & .404 & & \\
\hline & Total & 28.792 & 52 & & & \\
\hline
\end{tabular}

[Table 6] Differences in Reshoring Motivation by Country: Labour Factor

\begin{tabular}{|c|c|c|c|c|c|c|}
\hline \multicolumn{2}{|c|}{ Source of difference } & $\begin{array}{c}\text { Squared } \\
\text { sum }\end{array}$ & $\begin{array}{c}\text { Degree of } \\
\text { freedom }\end{array}$ & $\begin{array}{c}\text { Mean } \\
\text { Square }\end{array}$ & F & Significance \\
\hline \multirow{3}{*}{ LF1 } & Between groups & 17.439 & 2 & 8.720 & 17.697 & .000 \\
\cline { 2 - 7 } & Within groups & 24.636 & 50 & .493 & & \\
\cline { 2 - 7 } & Total & 42.075 & 52 & & & \\
\hline \multirow{3}{*}{ LF2 } & Between groups & 10.009 & 2 & 5.005 & 8.694 & .001 \\
\cline { 2 - 7 } & Within groups & 28.783 & 50 & .576 & & \\
\cline { 2 - 7 } & Total & 38.792 & 52 & & & \\
\hline \multirow{3}{*}{ LF3 } & Between groups & 1.160 & 2 & .580 & 1.063 & .353 \\
\cline { 2 - 7 } & Within groups & 27.292 & 50 & .546 & & \\
\cline { 2 - 7 } & Total & 28.453 & 52 & & & \\
\hline
\end{tabular}

[Table7] Differences in Reshoring Motivation by Country: Country Factor

\begin{tabular}{|c|c|c|c|c|c|c|}
\hline \multicolumn{2}{|c|}{ Source of difference } & Squared sum & $\begin{array}{l}\text { Degree of } \\
\text { freedom }\end{array}$ & $\begin{array}{c}\text { Mean } \\
\text { Square }\end{array}$ & $\mathbf{F}$ & Significance \\
\hline \multirow{3}{*}{ CF1 } & Between groups & 30.836 & 2 & 15.418 & 44.424 & .000 \\
\hline & Within groups & 17.353 & 50 & .347 & & \\
\hline & Total & 48.189 & 52 & & & \\
\hline \multirow{3}{*}{ CF2 } & Between groups & 1.528 & 2 & .764 & 2.363 & .105 \\
\hline & Within groups & 16.170 & 50 & .323 & & \\
\hline & Total & 17.698 & 52 & & & \\
\hline \multirow{3}{*}{ CF3 } & Between groups & 1.052 & 2 & .526 & 1.173 & .318 \\
\hline & Within groups & 22.420 & 50 & .448 & & \\
\hline & Total & 23.472 & 52 & & & \\
\hline \multirow{3}{*}{ CF4 } & Between groups & 3.997 & 2 & 1.998 & 4.525 & .016 \\
\hline & Within groups & 22.079 & 50 & .442 & & \\
\hline & Total & 26.075 & 52 & & & \\
\hline \multirow{3}{*}{ CF5 } & Between groups & 11.742 & 2 & 5.871 & 11.719 & .000 \\
\hline & Within groups & 25.050 & 50 & .501 & & \\
\hline & Total & 36.792 & 52 & & & \\
\hline
\end{tabular}




\begin{tabular}{|c|c|c|c|c|c|c|}
\hline \multirow{3}{*}{ CF6 } & Between groups & 1.712 & 2 & .856 & 1.417 & .252 \\
\cline { 2 - 7 } & Within groups & 30.212 & 50 & .604 & & \\
\cline { 2 - 7 } & Total & 31.925 & 52 & & & \\
\hline
\end{tabular}

To test the Hypothesis 4, this paper conducted a t-test to compare the mean differences between the two industry types. [Table 10] shows the results. There are few differences in reshoring motivation and performance by industry type except for the five factors (i.e., CS4; RM1, 2 and 3; LF3; and OI2). Regarding CS4, knowledge and technology-based industry have a higher mean value than that of traditional manufacturing, and the difference is statistically significant. This result implies that when making reshoring decisions, companies in the knowledge and technology-based industry are more motivated to seek a new product mix with novel value than are companies in the traditional manufacturing industry. Regarding risk management factors, the traditional manufacturing industry shows a higher mean value than that of the knowledge and technology-based industry. This suggests that compared to companies in the traditional manufacturing industry, those in the knowledge and technology-based industry are more risk taking and that in their reshoring decisions, they are less motivated by the need for risk management. For the Labour factor (LF), the two industries both have low mean values, but the value is lower in the traditional manufacturing industry. Regarding the OI2 performance factor, the knowledge and technology-based industry has a higher mean value than that of the traditional manufacturing industry. This implies that compared to companies in the traditional manufacturing industry, companies in the knowledge and technology-based industry are more proactive about expanding to new business markets and entering into new industry sectors using reshoring strategies. Having presented the above results in the local context, this research supports the Hypotheses $1,2,3$ and 4 in a partial manner

[Table 8] Differences in Reshoring Performance by Country

\begin{tabular}{|c|c|c|c|c|c|c|}
\hline \multicolumn{2}{|c|}{ Source of difference } & Squared sum & $\begin{array}{l}\text { Degree of } \\
\text { freedom }\end{array}$ & Mean Square & $\mathrm{F}$ & Significance \\
\hline \multirow{3}{*}{ CST1 } & Between groups & 5.556 & 2 & 2.778 & 6.107 & .004 \\
\hline & Within groups & 22.745 & 50 & .455 & & \\
\hline & Total & 28.302 & 52 & & & \\
\hline \multirow{3}{*}{ CST2 } & Between groups & 5.826 & 2 & 2.913 & 5.409 & .007 \\
\hline & Within groups & 26.929 & 50 & .539 & & \\
\hline & Total & 32.755 & 52 & & & \\
\hline \multirow{3}{*}{ QUA1 } & Between groups & .145 & 2 & .072 & .221 & .802 \\
\hline & Within groups & 16.383 & 50 & .328 & & \\
\hline & Total & 16.528 & 52 & & & \\
\hline \multirow{3}{*}{ QUA2 } & Between groups & .277 & 2 & .139 & .552 & .579 \\
\hline & Within groups & 12.553 & 50 & .251 & & \\
\hline & Total & 12.830 & 52 & & & \\
\hline \multirow{3}{*}{ QUA3 } & Between groups & 1.621 & 2 & .810 & 1.654 & .202 \\
\hline & Within groups & 24.492 & 50 & .490 & & \\
\hline & Total & 26.113 & 52 & & & \\
\hline \multirow{3}{*}{ OI1 } & Between groups & 1.477 & 2 & .739 & 1.908 & .159 \\
\hline & Within groups & 19.353 & 50 & .387 & & \\
\hline & Total & 20.830 & 52 & & & \\
\hline \multirow{3}{*}{ OI2 } & Between groups & 2.295 & 2 & 1.147 & 3.906 & .027 \\
\hline & Within groups & 14.686 & 50 & .294 & & \\
\hline & Total & 16.981 & 52 & & & \\
\hline
\end{tabular}


[Table 9] Differences in Reshoring Motivation and Performance by Industry Type

\begin{tabular}{|c|c|c|c|c|c|c|}
\hline \multirow{3}{*}{ Variables } & \multicolumn{4}{|c|}{ Industry Type } & \multirow{3}{*}{ T-value } & \multirow{3}{*}{$\mathrm{P}$} \\
\hline & \multicolumn{2}{|c|}{$\begin{array}{l}\text { Traditional manufacturing } \\
\qquad(\mathrm{n}=35)\end{array}$} & \multicolumn{2}{|c|}{$\begin{array}{c}\text { Knowledge and Technology based } \\
\text { industry } \\
(\mathrm{n}=18)\end{array}$} & & \\
\hline & Mean & S.D & Mean & S.D & & \\
\hline RR1 & 3.885 & .758 & 3.888 & .676 & .015 & .988 \\
\hline RR2 & 3.942 & .683 & 3.833 & .674 & .546 & .587 \\
\hline RR3 & 4.142 & .692 & 4.166 & .618 & -.123 & .903 \\
\hline CS1 & 3.774 & .645 & 3.777 & .618 & -.031 & .975 \\
\hline $\mathrm{CS} 2$ & 3.857 & .601 & 4.055 & .539 & -1.777 & .245 \\
\hline $\mathrm{CS} 3$ & 3.885 & .718 & 4.222 & .808 & -1.548 & .128 \\
\hline CS4 & 3.685 & .832 & 4.278 & .826 & -2.459 & $.017 * *$ \\
\hline CS5 & 3.913 & .817 & 4.111 & .900 & -.802 & .426 \\
\hline SEF1 & 3.542 & .657 & 3.5 & .514 & .241 & .811 \\
\hline SEF2 & 3.714 & .667 & 3.444 & .511 & 1.501 & .139 \\
\hline SEF3 & 3.657 & .725 & 3.722 & .751 & -.306 & .761 \\
\hline RM1 & 4.257 & .505 & 4.000 & .343 & 1.937 & $.058^{*}$ \\
\hline RM2 & 4.228 & .490 & 3.944 & .539 & 1.932 & $.059 *$ \\
\hline RM3 & 4.514 & .701 & 4.000 & .685 & 2.546 & $.014 * *$ \\
\hline RM4 & 4.257 & .505 & 4.166 & .618 & .572 & .570 \\
\hline RM5 & 4.142 & .772 & 4.166 & .707 & -.109 & .913 \\
\hline LF1 & 3.742 & .816 & 4.111 & 1.022 & -1.425 & .160 \\
\hline LF2 & 3.885 & .866 & 3.777 & .878 & .427 & .671 \\
\hline LF3 & 2.742 & .816 & 2.388 & .501 & 1.678 & $.099 *$ \\
\hline CF1 & 3.657 & 1.083 & 3.611 & .697 & .163 & .871 \\
\hline CF2 & 4.000 & .594 & 4.222 & .548 & -1.323 & .192 \\
\hline CF3 & 4.114 & .718 & 4.277 & .574 & -.837 & .407 \\
\hline CF4 & 3.914 & .742 & 3.777 & .646 & .661 & .512 \\
\hline CF5 & 3.942 & .872 & 3.666 & .766 & 1.135 & .262 \\
\hline CF6 & 3.971 & .785 & 3.944 & .802 & .118 & .907 \\
\hline CST1 & 3.257 & .657 & 3.277 & .894 & -.096 & .924 \\
\hline CST2 & 3.314 & .718 & 3.222 & .942 & .397 & .693 \\
\hline QUA1 & 3.828 & .568 & 4.055 & .539 & -1.401 & .167 \\
\hline QUA2 & 4.000 & .542 & 4.166 & .383 & -1.161 & .251 \\
\hline QUA3 & 3.742 & .657 & 3.944 & .802 & -.980 & .332 \\
\hline OI1 & 4.000 & .594 & 3.833 & .707 & .906 & .369 \\
\hline OI2 & 3.885 & .582 & 4.166 & .514 & -1.727 & $.090^{*}$ \\
\hline
\end{tabular}

\section{Discussion}

This study analysed whether the motives and performance of reshoring international companies differ by country and industry. Summarizing this study's results, first, all countries (i.e., the US, Japan, and Korea) showed strong motives for reconfiguration, restricted cost, and risk management factors. With respect to these motivation factors, this study found no differences between countries. However, with respect to customer service, labour and country factors, a number of items showed between-country differences. In detail, US and Japan showed higher averages than Korea for those three factors. This suggests that in US and Japan, the domestic market is relatively large and important, and companies reshore to further improve their services to their domestic customers and thereby realize increased profits. On the other hand, Korea's domestic market size and profit potential are relatively lower; thus, there is less of an incentive to reshore to enhance customer service if it means facing a short-term cost increase. Regarding labour and country factors, the US and Japanese governments more actively encourage reshoring by offering strong incentives to companies. As a result, companies in those countries are highly motivated to reshore to realize advantages.

Regarding reshoring performance, the quality of products and services factor and the organizational innovation factor showed high average values in all three countries. This means that reshoring helps 
companies improve the quality of their products and services as well as enhances their organizational innovation. It was also found that reshoring performance varies by country. In particular, the cost and organizational innovation elements tended to differ by country, with US and Japanese companies having higher mean values than those of the Korean companies. This result implies that reshored companies in advanced countries such as the US and Japan may enjoy cost-based advantages and organizational innovational benefits from reshoring. Conversely, no significant difference was found between countries in the quality of products and services factor. This implies that not only in the US and Japan but also in Korea, reshoring companies are reaping the benefit of improved quality in their products and services.

The results regarding differences in reshoring motivation and performance by industry are as follows. The mean value for motivation to improve customer service was significantly higher in the knowledge and technology-based industries than in the traditional manufacturing industry. This implies that companies in knowledge and technology-based industries are more strongly motivated to improve products and added value in their home countries by proactively utilizing technology-related cluster effects. In addition, risk management and labour factors were higher in the traditional manufacturing industry. This implies that companies in the traditional manufacturing industry are less inclined to take risks, preferring a safer environment compared to companies in technology and knowledge-based industries. In addition, the tendency to increase cost advantages by improving labour productivity would have a higher value in the traditional manufacturing industry. In terms of reshoring performance, it was found that the achievements of organizational innovation (e.g., introducing new technologies) are higher in technology and knowledge-based industries. This suggests that due to characteristics of the industry, companies in technology and knowledge-based industries tend to acquire and utilize new technologies and knowledge more than companies in traditional manufacturing industries do.

\section{Conclusions}

The findings of this paper have meaningful implications to the supply chain management of international companies planning to reshore in the future. Many advanced countries have been promoting reshoring for its positive economic and employment effects. From the standpoint of individual companies, however, this option must be weighed carefully. While the incentives offered by a home country's government may seem attractive, a company must carefully consider its industry's characteristics and whether the governmental incentives are matched to the company's internal and external circumstances. Since reshoring can increase restructuring and reconfiguration costs in the short term, these costs as well as the expected effectiveness of the reshoring should be carefully analysed. As improvements in corporate innovation cannot be achieved in the short term and must be cultivated in a long-term way, companies may face substantial difficulty in accurately estimating reshoring effects and determining their final course of action. The international business environment changes rapidly on a daily basis, and the recent Covid-19 pandemic is yet another important factor to consider in the decision to reshore. Therefore, reshoring decisions should not be based on fragmentary information. Rather, they should be approached strategically with an integrated, macroscopic view of a company's global supply chain management.

This study does, however, have a few limitations. Firstly, as the norm for empirical investigations, the greater the number of sampled companies, the stronger the base for the generalizability of the findings. Follow-up research is imperative. Secondly, the research findings presented in this paper are of overseasbased, global companies investing and operating in the local context of Korea. Thus, further research needs to expand the scope for investigation in terms of the survey region and respondent characteristics for detailed analysis. 


\section{Acknowledgments}

This work was supported by the Ministry of Education of the Republic of Korea and the National Research Foundation of Korea(NRF-2021S1A5A2A01063692).

\section{References}

[1] J. V. Gary, G. Esenduran, M. J. Rungtusamatham, K. Skowronski, (2017), Why in the world did they reshore? Examining small to medium sized manufacturer decisions, Journal of Operations Management, (2017), Vol.49-51, No.1, pp.37-51, DOI: https://doi.org/10.1016/j.jom.2017.01.001

[2] M. Mohiuddin, M. Rashid, M. Samim, Z. Su, Back-shoring or re-shoring: determinants of manufacturing offshoring from emerging to least developing countries (LDCs), International Journal of Logistics Research and Applications, (2018), Vol.22, No.1, pp.78-97, DOI: https://doi.org/10.1080/13675567.2018.1475554

[3] B. Wiesmann, J. R. Snoei, P. Hilletofth, D. Eriksson, Drivers and barriers to reshoring: a literature review on offshoring in reverse, European Business Review, (2017), Vol.29, No.1, pp.15-42, DOI: https://doi.org/10.1108/EBR-032016-0050

[4] B. Dachs, S. Kinkel, A. Jager, Bringing it all back home? Backshoring of manufacturing activities and the adoption of Industry 4.0 tehcnologies, Journal of World Business, (2019), Vol.54, No.6, pp.1-15, DOI: https://doi.org/10.1016/j.jwb.2019.101017

[5] J. Stentoft, O. S. Mikkelsen, J. K. Jensen, C. Rajkumar, Performance outcomes of offshoring, backshoring and staying at home manufacturing, Internatioanl Journal of Production Economics, (2018), Vol.199, pp.199-208, DOI: 10.1016/j.jpe.2018.03.009

[6] A. Ancarani, C. Di Mauro, L. Fratocchi, G. Orzes, M.Sartor, Prior to reshoring: a duration analysis of foreign manufacturing ventures, International Journal of Production Economy, (2015), Vol.169, pp.141-155, DOI:10.1016/j.ijpe.2015.07.031

[7] Nassimbeni Guido, Sartor Marco, Wan Li, Ancarani Alessandro, Di Mauro Carmela, Mascali Francesco, Barbieri Paolo, Di Stefano Cristina, Fratocchi Luciano, Iapadre Lelio, Orzes Guido, Reshoring in Europe: Overview 2015-2018, Eurofound, (2019), https://www.eurofound.europa.eu/mt/publications/report/2019/reshoring-in-europe-overview2015-2018

[8] S. J. Nam, M. K. Bang, Analysis on reshoring of major countries and determinants - Focused on the Influence of Technology Innovation after the Fourth Industrial Revolution, The Comparative Economic Review, (2019), Vol.26, No.1, pp.135-169, DOI: 10.23014/kace.26.1.201906.133

[9] Summary of the 48th Basic Survey on Overseas Business Activities, Ministry of Economy, pp.1-14, (2018), https:/www.meti.go.jp/english/statistics/tyo/kaigaizi/pdf/h2c411je.pdf

[10 ] S. W. Lee, C. W. Kwon, C. H. Choi, The Determinants of Reshoring in South Korea, Journal of Social Science, (2016), Vol.55, No.1, pp. 209-233, UCI: G704-SER000010755.2016.55.1.007

[11] https://www.retalkasia.com/blog/cynthia-chu/reshoring-offshorers, Jan 14 (2019)

[12] Worldbank, World development indicators, https://databank.worldbank.org/source/world-development-indicators, Sept $6(2021)$

[13] KOTRA, https://www.kotra.or.kr/biz/, Oct 20 (2020) 